\title{
New Technology in Modern Dikir Barat: Consideration of Acceptance and Development in The Kelantan Community
}

\author{
Azlina Musa ${ }^{* 1}$, Rabiu Muazu Musa ${ }^{1}$ and Mohd Nasir Hashim ${ }^{2}$ \\ ${ }^{1}$ Centre for Foundation and Continuing Education, Universiti Malaysia Terengganu (UMT), Terengganu, Malaysia \\ ${ }^{2}$ Universiti Malaya, Kuala Lumpur, Malaysia \\ *Corresponding author email: azlinamusa@umt.edu.my
}

\begin{abstract}
Berdikir is the singing of the Kelantan dialect en masse with a loud voice according to a certain rhythm. Dikir barat serves as a symbol of identity, as well as a form of entertainment that is linked with the cultural life of the local community in the state of Kelantan, Malaysia. The advent of technology has somewhat modernized its classical features which in turn reflects that the original nature of the song seems difficult to preserve. This study examines the application of new technologies in the modern dikir barat towards its acceptance and development in the Kelantan community. A total of 200 questionnaires were developed and distributed. The samples of the study consisted of the active participants of the dikir show with age range from 13 until 100 . The data collected were analyzed to determine the acceptance of the modern form dikir as well as the extent of development brought to the community by the application of the technology to the modern dikir. It was observed from the finding of the study that the community accepted the new modern dikir barat. Moreover, the finding reveals the new modern dikir could attract more people as opposed to the oldern dikir barat which may promote tourism activity in Kelantan. It can be included from the findings of the present study that the use of modern technology in the classical music has transformed the way people perceived music which go a long way in fostering its overall acceptance and contributing to the community participation.
\end{abstract}

Keywords: technology in modern music, dikir, Malaysian tradition, community entertainment, Kelantan

\section{INTRODUCTION}

Dikir barat is an art form which is both traditional and popular in Kelantan. It involves solo and group singing, hand clapping, synchronized body and hand movements, accompanied by percussion instruments [1]-[4]. According to Halid [5], dikir barat today is not only popular in its place origin Kelantan but has been well received throughout the nation. Dikir barat has also branched into difference genres with new songs performed by a solo or duet artist with modern music accompaniment [6]-[9].
According to Don [10], the Kelantanese dialect has been a central component in the ethnolinguistic formation for the people of Kelantan in the process of constructing an inclusive sense of statehood and also of maintaining membership of being Kelantanese. This is crucial in the expansion of dikir barat as not only a traditional art form, but also as popular culture and in creating a new Kelantanese identity [11]-[13]. 
Among the objectives of this study was to examine the factors of community acceptance of dikir barat in Kelantan. In addition, this study is conducted to examine the development and changes in western dikir in Kelantan.

\section{METHODOLOGY}

This study is based on field observation methods. In addition to the questionnaire method for 211 respondents and interviews is also conducted as a complement to the study conducted.

\section{RESULTS}

The results of the study conducted show that gender is based on men and women. The results show that women are 117 or $55.5 \%$. While men are 94 or $44.5 \%$. The results of the study show that women are more interested in dikir barat than men.

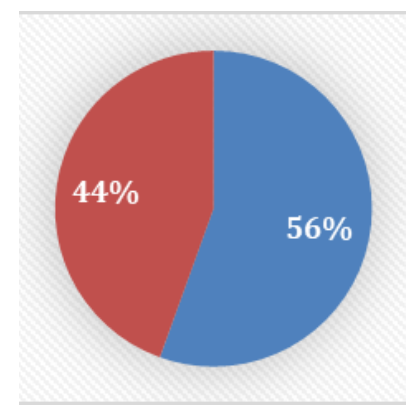

Figure 1 Gender

Furthermore, the results of the study show that 158 or $74.9 \%$ are aware of dikir barat in Kelantan. While 53 or $25.1 \%$ are unaware of dikir barat in Kelantan. The results of the study show that the community is aware of the existence of dikir barat in Kelantan. The results of the study show that dikir barat performances that incorporate new genre elements are able to deliver dikir barat performances in the audience. Dikir barat is able for the community to recognize the performance of the dikir barat.

In addition, the results of the study also show that 132 or $62.6 \%$ have watched the dikir barat performance face to face. While 79 or $37.4 \%$ never watched the dikir barat performance face to face. The results of the study show that the community has watched the dikir barat performance face to face. The results of the study show that the dikir barat performance face to face in the audience is always presented in the audience. The dikir barat performance in the audience is to introduce the dikir barat performance art which is part of the traditional heritage.

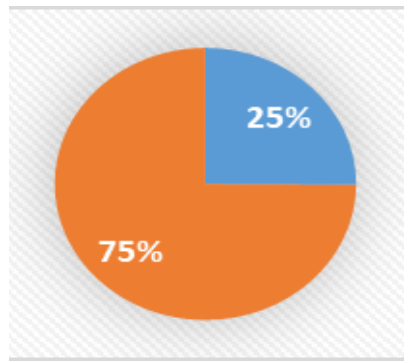

Figure 2 Knowlegde

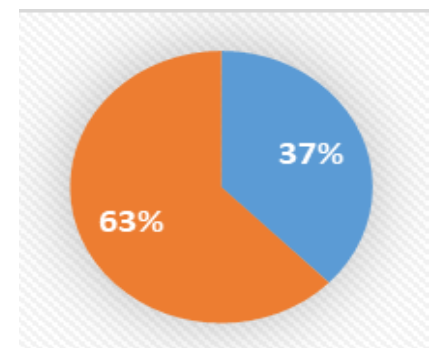

Figure 3 Performance Dikir Barat

The results of the study also showed that 138 or $65.4 \%$ had ever watched the dikir barat performance on you tube. While 73 or $34.6 \%$ have never watched a western dikir performance on you tube. Accordingly, the results of the study show that most of the easy access is the ability to watch dikir barat performances on you tube. The dikir barat performance on you tube is easy for someone to access listening to or watching the dikir barat performance on you tube. According to Halid [5], the internet is another avenue in which dikir barat is heavily promoted. Numerous websites on dikir barat can be found, allowing the free downloading of songs, videos and providing rooms for discussions among enthusiasts. Dikir barat also goes online. Albums, performances and artists are promoted through the internet, while songs and videos are freely uploaded on you tube and other sites.

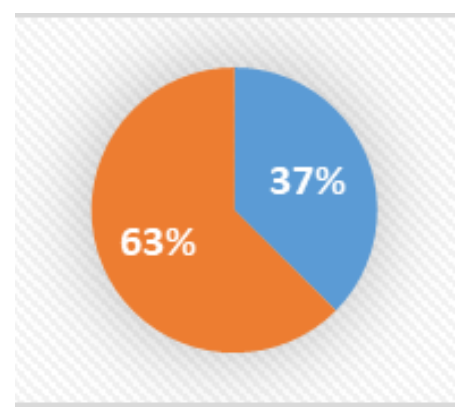

Figure 4 Watched Dikir Barat in YouTube 
The results of the study also show that 143 or $67.8 \%$ have heard or watched dikir barat performances that have elements of rap, hip hop, hindustan and others. While 68 or $32.2 \%$ have never heard or watched dikir barat performances such as rap music, hip hop, hindustan and others. The results of the study show that the community can listen or watch dikir barat performances that apply elements of rap music, techno, hip hop and so on. In this regard, the results of the study show that most people have heard or watched the performance of dikir barat.

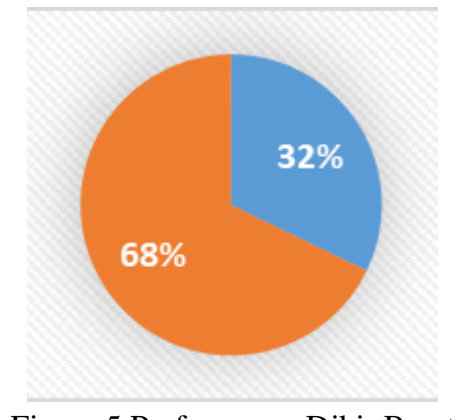

Figure 5 Performance Dikir Barat

The results also show that 112 or $53.1 \%$ are once a year listening to or watching dikir barat performances. While 42 or $19.9 \%$ is once a month listening or watching dikir barat performances. While 29 or $13.7 \%$ are once a week listening or watching dikir barat performances. While 28 or $13.3 \%$ are daily listening to or watching dikir barat performances. The results of the study show that dikir barat music is rarely heard by most people. This is because the results of the study show that once a year is the highest that describes the dikir barat music is not entertainment music that can satisfy the tastes of the listener as a whole.

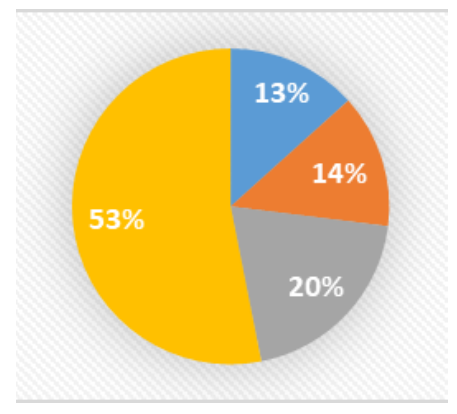

Figure 6 Watching Dikir Barat

Next is the level of acceptance of dikir barat. The results showed that 131 or $62.1 \%$ were satisfactory in accepting dikir barat. While 38 or $18 \%$ is very good acceptance of dikir barat. While 25 or $11.8 \%$ is less favorable dikir barat acceptance. While 17 or $8.1 \%$ is not good at accepting dikir barat. The results of the study show that dikir barat music is well received among the community. This is because dikir barat music is capable of providing entertainment to the community.

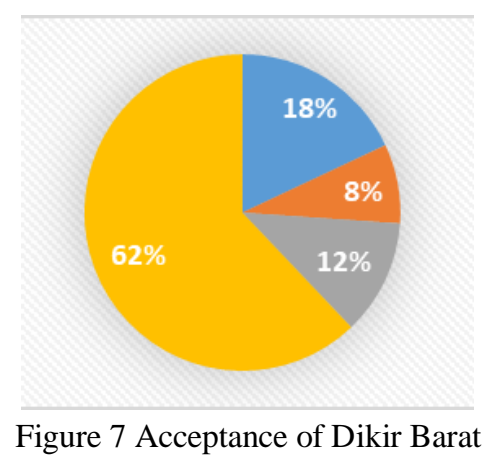

Next is the pleasure of listening or watching dikir barat rap, hip hop, hindustan and others is 105 or $49.8 \%$ like to listen or watch dikir barat rap, hip hop, hindustan and others. While 58 or $27.5 \%$ are satisfied like listening to or watching dikir barat music rap, hip hop, hindustan and others. While 27 or $12.8 \%$ do not like to listen or watch dikir barat music rap, hip hop, hindustan and others. While 21 or $10 \%$ are very fond of listening to or watching dikir barat music rap, hip hop, hindustan and others. The results of the study show that dikir barat music in the genre is able to attract the interest of the public to listen to dikir barat music.

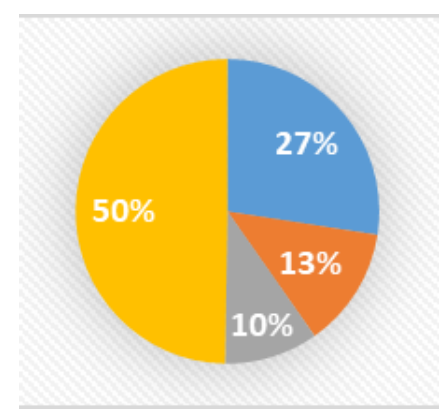

Figure 8 Liking to Listen Dikir Barat

Next is the satisfaction of listening or watching dikir barat performances of rap, hip hop, hindustan and others. The results of the study show that 110 or $52.1 \%$ are satisfied to listen or watch the performance of dikir barat rap, hip hop, hindustan and others. While 51 or $24.2 \%$ are satisfied to listen or watch the performance of dikir barat rap, hip hop, hindustan and others. While 27 or $12.8 \%$ are very satisfied to hear or watch the performance of dikir barat rap, hip hop, hindustan and others. While 23 or $10.9 \%$ are dissatisfied with listening to or watching dikir barat performances of rap, hip hop, hindustan and others. The 
results of the study show that dikir barat music is capable of providing satisfaction to the listening community.

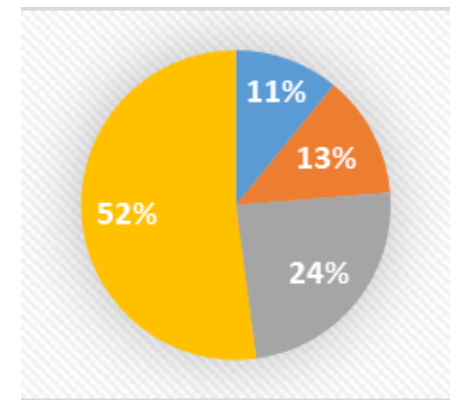

Figure 9 Satisfaction of Dikir Barat

While the level of dikir barat celebration in Kelantan by the community. The results show that 100 or $47.4 \%$ is a good response in dikir barat in Kelantan. While 55 or $26.1 \%$ is satisfactory dikir barat celebration in Kelantan. While 29 or $13.7 \%$ is very encouraging dikir barat celebration in Kelantan. While 27 or $12.8 \%$ is no dikir barat celebration in Kelantan. The results of the study show that dikir barat which applies elements of music genre rap, techno, hip hop and so on is well received by dikir barat among the community.

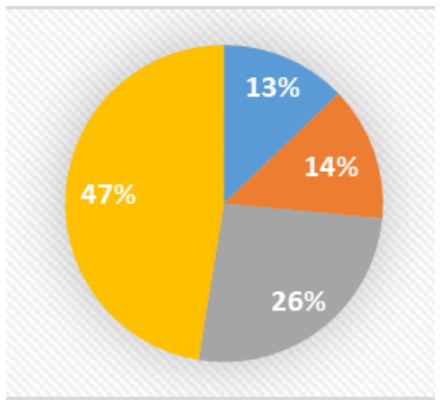

Figure 10 Dikir Barat Celebration in Kelantan

Next is to examine the preferences if the musical elements that have the genre of rap, hip hop and so on are maintained in the dikir barat in Kelantan. The results of the study show that 111 or $52.6 \%$ would like if the music genre rap, hip hop and so on are maintained in dikir barat in Kelantan. While 45 or $21.3 \%$ is satisfying if the music of the genre of rap, hip hop and so on is maintained in dikir barat in Kelantan. While 33 or $15.6 \%$ do not like if the music genre rap, hip hop is maintained in dikir barat in Kelantan. While 22 or $10.4 \%$ are very fond if the music genre rap, hip hop is maintained in dikir barat in Kelantan. In this regard, the result of the study is that the community likes to listen or watch dikir barat performances that apply musical elements of the genre of rap, hip hop and so on in dikir barat in Kelantan. This is because the dikir barat music is capable of attracting the younger generation to like and interest in the dikir barat music.

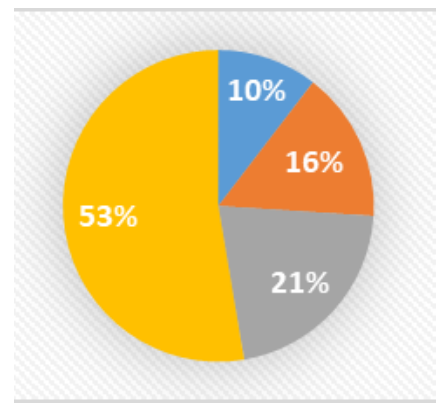

Figure 11 Maintained in The Dikir Barat

Next is the development of dikir barat in Kelantan today. The results show that the level of development of dikir barat in Kelantan today is 99 or $46.9 \%$ is horizontal development of dikir barat in Kelantan. While 78 or $37 \%$ is increasing the development of dikir barat in Kelantan. While 34 or $16.1 \%$ is decreasing the development of dikir barat in Kelantan. In this regard, the results of the study show that the development of dikir barat which applies elements of music genre rap, techno, hip hop and so on is horizontal dikir barat in Kelantan that is the development is still balanced dikir barat since long ago and today is still relevant and not swallowed by the times.

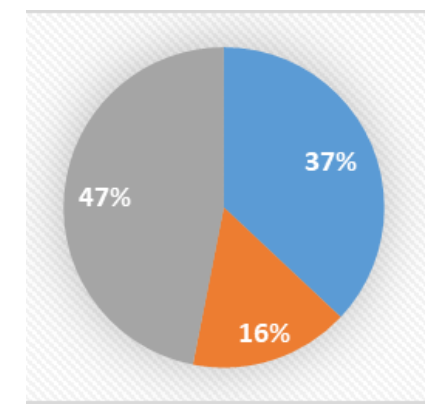

Figure 12 Development Dikir Barat

\section{CONCLUSION}

Based on the findings of the study conducted in relation to that, the discussion of the study is to show that dikir barat which applies elements of music genre rap, techno, hip hop and so on is well received, especially among the younger generation today. Dikir barat is an activity that is able to attract the interest of the younger generation to appreciate the heritage art of Kelantan. Apart from that, the dikir barat has the ability to cultivate interest among the younger generation and a hobby among the younger generation to like the dikir barat. In addition, the dikir barat is able to produce more young people to participate 
in their involvement in the dikir barat as part of the activities that they should complete in their free time. In addition, the dikir barat is to ensure that the dikir barat is still relevant and not eradicated by time so that it can be maintained as a national heritage treasure.

\section{ACKNOWLEDGMENT}

The authors thank the participants for their cooperation and support throughout the data collection process.

\section{REFERENCES}

[1] G. Y. Soon, L. C. Chuen, N. K. Leng, Comparing the Usefulness of Two Singing Modes to Support Chinese Learning: Karaoke and Dikir Barat in Mandarin. Mediterranean Journal of Social Sciences, 6 (6S2) (2015), 684-690.

[2] A. Musa, Modern Technology Trends Bring the Chance of Identity Originality Dikir Barat in Kelantan. International Journal of Engineering and Advanced Technology, 9 (4) (2020), 495-498.

[3] A. A. B. Ismail, D. A. Ghani, Puteri Saadong by using Dikir Barat Approach. Journal of Engineering and Applied Sciences, 15 (2020), 3164-3167.

[4] S. Bahri, K. S. Lee, M. A. Adenan, M. K. Murugiah, T. M. Khan, C. F. Neoh, C. M. Long, Dikir Farmasi: folk songs for health education. Arts \& Health, 8 (3) (2016), 272-278.

[5] R. I. R. Halid, Modernizing tradition: the media and dikir barat of Kelantan. Scottish Journal of Arts, Social Sciences and Scientific Studies, 20 (1) (2014), 27-36.

[6] S. A. Ahmad, H. A. Halim, N. R. N. M. Affendi, Unsur Pengulangan Dalam Lirik Lagu Dikir Barat. Jurnal Linguistik, 22 (2) (2018), 1-9.

[7] C. Brennan, Religion, cultural identity, and Kelantan's dikir barat. (Part 2 religious discourses and the state). The Australian Journal of Anthropology, 12 (3) (2001).

[8] W. Chatawaraha, The Dikir Barat Music of the Malaysian-Siamese in Kelantan, Malaysia. Rangsit Music Journal, 12 (1) (2017), 69-85.
[9] M. F. Ismail, S. J. N. Muhammad, M. F. C. Yaacob, Unsur Amanat dan Impak Lirik Dikir Barat Halim Yazid. International Journal of Language Education and Applied Linguistics, 4 (2016), 67-80.

[10] Z. M. Don, Kelantanese in a new ethnolinguistic environment. International Journal of the Sociology of Language, 2 (161) (2003), 55-79.

[11] C. Tassanawongwara, Malaysian Siam Music in Northern Malaysia and Its Representation. IJCAS, 4 (2) (2017), 9-18.

[12] S. Tohsan, The Creation of "Thainess" through "Dhamma" and "Preaching" of Thai-Siamese People in Semerak, Kelantan State, Malaysia. Journal of Arts \& Humanities, 9 (2) (2020), 98-107.

[13] S. Tohsan, Space" and Identity Creation of Thai Siam People in Kelantan, Malaysia. Journal of Arts \& Humanities, 8 (4) (2019), 76-86. 